\title{
Plasticity of cancer stem cell: origin and role in disease progression and therapy
}

resistance

\section{Running Head: Plasticity of cancer stem cells}

Plabon Kumar Das ${ }^{1}$, Suja Pillai ${ }^{2}$, Md. Abdur Rakib ${ }^{1}$, Jahan Ara Khanam ${ }^{1}$, Vinod Gopalan ${ }^{3}$, Alfred K Y Lam ${ }^{3}$, Farhadul Islam ${ }^{1,2} *$

${ }^{1}$ Department of Biochemistry and Molecular Biology, University of Rajshahi, Rajshahi-6205, Bangladesh

${ }^{2}$ School of Biomedical Sciences, Faculty of Medicine, University of Queensland, Brisbane Qld 4029, Australia

${ }^{3}$ School of Medicine, Griffith University Gold Coast campus, Gold Coast-4222, Queensland, Australia

Plabon Kumar Das, MSc

Email :f.islam@griffith.edu.au

Research Link: https://www.researchgate.net/profile/Plabon_Das

Suja Pillai, PhD

Email :s.pillai@uq.edu.au

Md. Abdur Rakib, PhD

Email :mar@ru.ac.bd

Prof. Jahan Ara Khanam, PhD

Email:jak@ru.ac.bd

Vinod Gopalan, $\mathrm{PhD}$

Email :v.gopalan@griffith.edu.au

Prof. Alfred K Y Lam, PhD

Email :a.lam@griffith.edu.au

Farhadul Islam, PhD

Email: farhad bio83@ru.ac.bd

\section{*Correspondence to:}

Farhadul Islam, Department of Biochemistry and Molecular Biology, University of

Rajshahi, Rajshahi-6205, Bangladesh

Email: farhad_bio83@ru.ac.bd

Telephone $+8 \overline{8} 0-721-711109 ;$ Fax $+880-721-750064$

Suja Pillai, School of Biomedical Sciences, Faculty of Medicine, The University of Queensland, Brisbane Qld 4029, Australia

Email: s.pillai@uq.edu.au

Phone: +61 733655256 


\begin{abstract}
In embryonic development and throughout life, there are some cells, which can exhibit phenotypic plasticity. Phenotypic plasticity is the ability of cells to differentiate into multiple lineages. In normal development, plasticity is highly regulated whereas cancer cells reactivate this dynamic ability for their own progression. The re-activation of these mechanisms enables cancer cells to acquire a cancer stem cell (CSC) phenotype- a subpopulation of cells with the increased ability to survive in a hostile environment and resist therapeutic insults. There are several contributors, which fuel CSC plasticity in different stages of disease progression such as a complex network of tumour stroma, epidermal microenvironment and different sub-compartments within tumour. These factors play a key role in the transformation of tumour cells from a stable condition to a progressive state. In addition, flexibility in the metabolic state of CSCs helps in disease progression. Moreover, epigenetic changes such as chromatin remodeling, DNA methylation could stimulate the phenotypic change of CSCs. Development of resistance to therapy due to highly plastic behaviours of CSCs is a major cause of treatment failure in cancers. However, recent studies explored that plasticity can also expose the weaknesses in CSCs, thereby could be utilized for future therapeutic development. Therefore, in this review, we discuss how cancer cells acquire the plasticity, especially the role of the normal developmental process, tumour microenvironment, and epigenetic changes in the development of plasticity. We further highlight the therapeutic resistance property of CSCs attributed by plasticity. Also, outline some potential therapeutic options against plasticity of CSCs.
\end{abstract}

Keywords: CSC plasticity, cancer heterogeneity, tumour microenvironment, cancer metabolism, therapeutic resistance, therapeutic options 


\section{Introduction}

Cancer is a highly complex disease, displaying heterogeneity in different cancers and among cells within a single cancer [1]. The emergence of this complex process of tumour heterogeneity is always debatable and numerous cellular mechanisms e.g. metabolic switching, epigenetic alterations, deregulated signalling pathways etc. have been proposed to resolve the diversity between cancers and/or within cancer cells in a cancer [2]. In addition, plasticity (a process by which cancer cells gain the dynamic ability to switch from non-cancer stem cells to cancer stem cells and vice versa) has added further complexity to the highly discussed paradigm of tumour heterogeneity [3]. However, the plasticity of cancer stem cells (CSCs) could help in interpreting the heterogeneity observed in cancer [3]. CSCs, a subpopulation of cancer cells, associated with carcinogenesis, progression, resistance to therapy and cancer relapse, could directly switch between non-tumorigenic and tumorigenic cell states [4-5]. This reversible conversion capacity of CSCs attributes to protect themselves from chemo-radiotherapeutic insults [6-7]. Interestingly, this inter-conversion depends on the response to exogenous and endogenous stimuli and regulated by many factors including genetic evolution and phenotypic plasticity of CSCs $[8,9]$. Cellular interactions and specific microenvironmental signals in tumour niche contribute to the process of CSC plasticity. Tumour microenvironment primarily provides autocrine and paracrine signals in gaining CSC plasticity and proceeds through the formation of a complex signalling network. This process is aided by the involvement of numerous factors including exosomes, tumour-stroma interactions, composition of extracellular matrix and many more, which varies upon time and space in tumour progression [6-7]. Furthermore, interactions of a complicated array of signals couple with gene expression to control signalling pathways. Consequently, changes in gene expression causes individual cells to expose a variety of phenotypic states, which in turn facilitate tumour growth, metastasis and the resistance to chemotherapy [6-7]. 
Metabolic change in CSCs is another key regulator of plasticity, which affects their emergence and persistence throughout disease progression. Heterogeneous metabolic phenotypes i.e. various levels of glycolysis and oxidative phosphorylation were noted in CSCs, which are directly linked to carcinogenesis [10].

In addition, epigenetic deregulations such as alterations in chromatin and DNA methylation, resulting in genetic damages, trigger cellular plasticity and thereby facilitate oncogenic cellular reprogramming [11]. Subsequent epigenetic changes, which are resulted from the interaction within the tumour niche, revamp cancer cell's phenotypes and properties, thus formulating tumour architecture, which in turn affects the cellular states at multiple stages of cancer progression [11]. Hence, in the context of understanding tumourigenesis and its pathogenesis, plasticity of CSCs is vital. In this review we, therefore, discuss how could plasticity of CSCs evolve and the role of metabolism, tumour microenvironment and epigenetic changes in the development of plasticity of CSCs. We further discuss the role of CSC's plasticity in therapy resistance and illustrate ways to target this highly menacing property of CSCs.

\section{CSCs take over the developmental program of normal stem cell}

Plasticity of cells is crucial for the successful development of multi-cellular organism, especially in human. Thus, it is not surprising that cancer cells hijack this mechanism from normal stem cell for their own development [12]. The underlying mechanisms of normal reprogramming could be seized by cancer cells for generating less differentiated and more stem-like cells (CSCs) with different phenotypic plasticity. Epigenetic alterations along with oncogenic driver mutations could induce this reprogramming in CSCs [13-14]. This reprogramming involves reactivation of developmental programs, which in turn changes the adaptation capacity of tumour cells. In normal cells, differentiation states are strongly 
regulated through the activation and inactivation of transcriptional factors, which facilitate cellular plasticity during development [15]. Whereas in cancer, these factors coincide with those that contribute phenotypic plasticity as they are aberrantly activated (Figure 1). For instance, signalling pathways such as Notch and Wnt play prominent roles in cell fate switching, tissue patterning, and morphogenesis during normal development [15]. In cancer, these pathways can also contribute to the regulation of differentiation and self-renewal of CSCs in different molecular subtypes of cancer [15].

Phenotypic plasticity during tumour initiation is driven by the activation of developmental differentiation program, namely the epithelial-to-mesenchymal transition (EMT) [16]. EMT is a well-documented machinery of phenotypic plasticity in both normal and cancer cells. It plays a significant role in organogenesis during embryonic development, wound healing and cancer formation [17]. It is an essential ability of a cell to switch between epithelial to mesenchymal phenotypes during development [18]. For example, neural crest progenitor cells undergo EMT in the time of neural tube formation [19]. This process also occurs during embryonal development (gastrulation state) and formation of heart [16]. EMT is involved in undifferentiated or stem-like state, associated with the capacity of extended self-renewal and the acquisition of a stem-like genes expression [20]. However, some cancer cells undergo EMT whereas others do not, which could reflect intrinsic properties of their cell of origin. For example, inter-follicular epidermis and hair follicle tumour initiating cells shows distinct EMT properties [20]. Nevertheless, many of the molecular mechanisms of EMT in cancer are like EMT in normal cellular process such as in wound healing [5]. Other mechanisms contributing to cellular plasticity include activation of key-genes' transcription factors e.g. Snail, Zeb, and Twist families, which manoeuvre the transcriptional networks for de-differentiation by mediating specific interaction with DNA, thereby regulating gene expressions [21-23]. These transcriptional regulators not only regulate the transcription 
process in the normal development, but also play a significant role in cellular plasticity of CSCs. For instance, Zeb 1 regulates stemness, colonization capacity and phenotypic/metabolic plasticity of pancreatic adenocarcinoma driven by the activation of oncogenic Kras and deletion of p53 [24]. In addition, it promotes stem-like tumourigenic phenotype and resistance to MAPK inhibitors in melanoma stem cells [24]. Table 1 represents the factors involved in normal development and contributed in plasticity of CSCs.

In addition, tumour plasticity follows the normal developmental history of organs as they can gain cell fates involved in developmentally related neighbouring organs [25]. Defects in transcription factors programming are associated with embryonic cell-fate specification, which causes formation of tumour plasticity characterized by the acquisition of alternative cell fates of adjacent organs [25]. For example, downregulation of lineagespecifying transcription factor NKX2-1 from murine alveolar epithelium (not airway epithelium), resulted in the conversion of lung cells to gastric-like cells [25]. Similarly, in non-small cell lung carcinoma, loss of NKX2-1 causes accumulation of cancer like features in various gut tissues [25]. Therefore, the developmental programme appears to be a critical mechanism by which CSCs gain their ability to self-renew and maintain their plasticity.

\section{Extrinsic and intrinsic factors involved in plasticity of CSCs}

\subsection{Role of tumour microenvironment in plasticity of CSCs}

The tumour microenvironment is an important factor that contributes to the plasticity of cancer cells, including CSCs [26]. It is a complex network, consisting of tumour stroma, epidermal microenvironment and different sub-compartments within the tumour [26]. Many cellular and non-cellular factors from this microenvironment contribute to the transformation of tumour cells and may protect them from therapeutic insults [27]. It was demonstrated that CSCs, which are stimulated to gain plasticity as differentiated cancer cells could be 
reprogrammed in response to specific environmental signals, thereby reinitiating proliferation capacity and CSC-like features [27-28]. Accordingly, when cancer cells obtain specific signals from their microenvironment, they fuel the mechanism of plasticity, causing shift from an unstable "static" hierarchical condition to a reprogrammed state [3]. Thus, the interactions with tumour microenvironment corroborate malignant behaviour of tumour cells and drive the mode of phenotypic plasticity of cancer cells. For instance, the interconnection between CSCs and non-CSCs neoplastic cells in stroma of pancreatic, breast, and colon cancer, where stromal cells secrete signalling factors, which are received by epithelial cells, causes signalling cascade to orchestrate an epithelial to mesenchymal transition [29-31]. Furthermore, this interaction triggers the generation of CSCs phenotype by the activation of paracrine Nodal/Activin signalling cascade [32-33].

The mutual communication between CSCs microenvironment and immune niche can induce cellular plasticity (Figure 2). For example, pro-inflammatory mediators such as tumour necrosis factor (TNF) and interleukin-6 (IL-6), secreted by immune cells of the tumour microenvironment, can regulate the phenotypic changes of CSCs [34]. This cytokine-driven plasticity of CSCs have been noted in breast carcinoma, melanoma, and lung carcinoma, where TNF and IL-6 can alter the differentiation state of CSCs by upregulating mesenchymal genes and promote EMT-type switch [3]. Moreover, in the absence of necessary factors required to revitalize self-renewal process, CSCs secrete IL-6 in order to attract mesenchymal stem cells (MSC), which in turn promote cancer cell stemness by

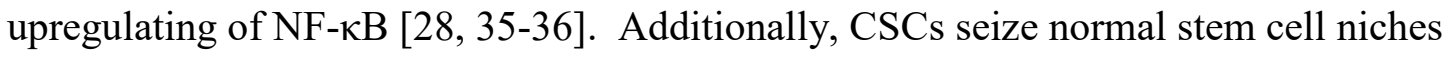
formed by MSCs for transforming surrounding cells to support CSCs to colonize the new niche [35]. Therefore, in such a microenvironment, tumour cells gain the capability of controlling immune response by facilitating the expansion of tumour-associated macrophages, tumour-associated neutrophils, myeloid-derived suppressor cells and dendritic 
cells (Figure 2). Subsequently, tumour-associated macrophages produce TNF- $\alpha$ and TGF- $\beta$, which in turn stimulate NF-אB or TGF- $\beta$-dependent induction of EMT and stemness pathways, resulting in further augmentation of self-renewal and plasticity of CSCs.

Hypoxia, another phenomenon of tumour microenvironment, can induce the transformation of non-CSCs to CSCs, thereby triggers plasticity of CSCs. Hypoxic stress in inconsistent tumour microenvironment can induce metabolic, epigenetic and phenotypic reprogramming of the cells [37-38]. Consequently, hypoxia can promote the capacity of a cell to switch from its original cellular state to a distinct one [39]. HIFs (Hypoxia-inducible factors) with pro-angiogenic and inflammatory factors such as VEGF, or TGF- $\beta$ could play important regulatory roles in hypoxia-induced CSC plasticity [40]. For example, HIF-2 $\alpha$ causes the release of angiogenic factors to promote the acquisition of CSC-like phenotype in glioblastomas [41]. In triple-negative breast carcinoma, hypoxia induces the acquisition of cancer stem-like phenotypic plasticity via upregulation and activation of STAT3 (signal transducer and activator of transcription-3) [42].

Biomechanical forces such as hydrodynamic shear stress might be an important microenvironmental factor, which leads to the generation of cancer stem-like cells or tumour initiating potential in cancer [43]. It was noted that shear stress facilitates the conversion of circulating tumour cells into distinct tumour initiating cells in blood circulation by enhancing plasticity via EMT through inhibiting ERK and GSK3 $\beta$ activities [43]. Also, in the presence of oxygen and nutrient gradient, melanoma spheroids separated themselves into a continuously proliferating subpopulation in the periphery, whereas a subpopulation of G1arrested cells in the centre [44]. Similarly, in human melanoma xenografts in mice, it was found that cells located near the blood vessels are going through the cycling process, whereas tumour cells in the centre are quiescent. Furthermore, when these two populations were cultured in a 2D culture plate, within 24 hours, G1arrested cells re-entered their cell cycle and 
not surprisingly, they became indistinguishable from the subpopulation of peripheral cells. Thus, these results indicate the phenotypic cellular plasticity model is influenced by specific environment. Therefore, CSC's function and plasticity may be affected by specific microenvironmental signals and cellular interactions originating from the tumour niche.

\subsection{Metabolic adaptation fuels plasticity of CSCs}

Metabolic plasticity is crucial for cancer cell adaptation. The complexity of CSC metabolism and their phenotypic behaviours are important prospects of cancer research. Normal stem cell depend heavily on oxidative phosphorylation (OXPHOS) for their energy, and a non-CSC cancer cell is primarily glycolytic, whereas CSC exhibits a solitary metabolic flexibility [45]. CSCs possess distinct metabolic profiles as they are endowed with elevated glucose consumption, lactate synthesis, and ATP production when compared to non-CSCs [46]. In addition, metabolic plasticity exists in CSCs of certain cancer subtypes, as well as can be found within the same cell type, thus contributing to metabolic heterogeneity [46]. Being a less differentiated phenotype, it is believed that CSCs depends mainly on glycolysis compared to their more differentiated counterpart [47]. However, to maintain homeostasis as well as tumour growth, CSCs can shift between OXPHOS and glycolysis. In various types of cancers such as in glioblastoma, lung carcinoma, colon carcinoma, osteosarcoma, ovarian carcinoma and breast carcinoma, CSCs strongly prefer the glycolytic pathway rather than more differentiated cancer cells [48-52]. Furthermore, stimulation of glycolysis by upregulation of glycolytic enzymes (e.g. GLUT1, HK-1, and PDK-1) is necessary for the longevity of CSCs [53-55]. In addition, reprogramming the metabolic shift from OXPHOS to glycolysis was shown to enhance the CSC properties [10]. Moreover, glycolysis was found to be the preferred metabolic program in radio-resistant nasopharyngeal carcinoma's CSCs and CD133 + CD49f + CSCs in hepatocellular carcinomas $[13,46]$. The underlying 
mechanism of CSC's metabolic switch towards glycolysis was evident by significant roles of STAT3 in cellular metabolism of STAT3 dependent CSCs [56]. Active STAT3 (Tyr 705) induces a metabolic switch to aerobic glycolysis and downregulates mitochondrial activity in primary fibroblasts and other STAT3-dependent CSCs [56]. On the contrary, a recent study demonstrated enhanced glycolysis as well as increased OXPHOS in CSCs [57]. However, higher rates of oxygen consumption and increased mitochondrial functions suggested a preference of OXPHOS in many types of cancers [58-60]. For example, CD133+ CSCs in glioblastoma and pancreatic adenocarcinoma, low reactive oxygen species quiescent leukaemia, side population (the population of cells which exclude dye and possess CSC property) of lung carcinoma, and side population of breast carcinoma prefer mitochondrial oxidative metabolism as the energy production process rather than glycolysis [58-60]. In CD133+ glioblastomas, insulin-like growth factor 2 mRNA binding protein (IMP2) maintains the metabolic switch to OXPHOS by directly interacting with several mitochondrial complex genes and regulating the expressions of stemness markers, including CD133, Sox2, Oct4 and Nanog [61]. Interestingly, in addition to the glycolytic and classical OXPHOS phenotypes, CSCs also rely on mitochondrial FAßO for ATP and NADPH generation (Figure 3). Thus, it is likely to occur that CSCs have adopted a relatively plastic metabolic state and can adjust to the settings in which the cells reside.

Accumulating evidence suggests various metabolic phenotypes in a tumour depending on their locations. Different compartments may be actively proliferating regions of the tumour, with adequate levels of oxygen, hypoxic areas of the tumour, and in a distant metastatic site $[45,62]$. For example, in normoxic condition where stemness has been associated with increased production of glycolytic enzymes, CSCs rely on glucose pathway along with mitochondrial pathway (Figure 3). Increased membrane potential, mitochondrial mass and mitochondrial fatty acid oxidation (FAO) for generation of ATP and nicotinamide 
adenine dinucleotide were noted in CSCs with sufficient levels of oxygen [62]. However, in hypoxic condition, where oxygen supply is deprived, hypoxia-inducible factors 1 (HIF-1) improves the up-regulation and activity of glycolytic proteins such as GLUT1, GLUT3 and various isoforms of glycolytic enzymes [63]. Moreover, in the metastatic niche, CSCs increases the utilization of extracellular catabolites, such as pyruvate, lactate, glutamate, glutamine, alanine, or ketone bodies [64]. On the other hand, in nutrient-deprived condition, CSCs maintain a quiescent state and the necessary energy acquired through autophagy [6567]. Therefore, putting aside the controversy about the metabolic phenotype of CSCs, metabolism is not only a key player but also a regulatory instigator of CSC's plasticity (Figure 3).

\subsection{Epigenetic mediated regulation of plasticity in CSCs}

Epigenetic mechanisms are the molecular processes that affect cell's behaviour via changing genes expression without genetic alterations [11]. They are primarily interceded by alterations in chromatin structure and DNA methylation pattern, which in turn confer genes differentially compatible for transcription [11]. It was demonstrated that various epigenetic changes in CSCs increase cellular plasticity and allow reversible transitions between different phenotypic states [11]. In addition, during initial carcinogenesis, changes in chromatin and DNA methylation resulting from epigenetic alterations trigger cellular plasticity and facilitate oncogenic cellular reprogramming. Epigenetic changes induced by chromatin or chromosomal rearrangement, are very common and crucial to maintaining the plasticity of CSCs [68]. For example, differentiated cancer (e.g. CD44 low) cells re-acquire self-renewal ability and reverse to a CSC (CD44 high) state by changing epigenetic and genetic makeup stimulated by TGF- $\beta$ in breast carcinoma [68]. Similarly, in melanoma, chromatin states can influence cancer cell plasticity [69]. It was found that a subpopulation of cells in melanoma 
is required for the continuous tumour growth and was distinguished by the expression of the histone demethylase JARID1B. This population transiently acquire stemness property depending on the tumour context [70]. On the other hand, histone acetylation, mediated by histone acetylases (HATs), regulates histone activity and increases gene expression by posttranslational modification (Figure 4). DNA methylation, another post-translational modification, favours CSCs formation and maintenance [71]. Importantly, proteins, (e.g. DNA methyltransferases, methylcytosine dioxygenases) associated with DNA methylation, have been identified as the drivers of CSC generation by controlling the nature of $\mathrm{CpG}$ dinucleotide formation (Figure 4). For example, in leukaemia and many solid tumours, changes in DNA methylation pattern leads to generation of CSCs [72-73].

\section{CSCs plasticity and therapy resistance}

There are several useful chemotherapeutic options exist for patients with cancer. However, development of therapeutic resistance is the major drawback and cause of treatment failure and disease recurrence. A few underlying mechanisms are associated with plasticity derived therapy resistance of CSCs [74-76]. Therapy resistance property of CSCs depends on the interplay between microenvironmental signals, metabolic adaptation, expression of transcription factors and epigenetic alterations etc., which in turn contribute to the plasticity of CSCs [77-79]. It was noted that cells exhibiting CSC or mesenchymal-like phenotype show enhanced resistance to conventional chemotherapeutic agents when compared with more differentiated or epithelial-like cancer cells [80]. These therapyresistant mesenchymal-like cells populations are responsible for cancer relapse after treatments [80]. In addition, the augmentation of CSCs phenotype after therapy could be due to the increased symmetric division of these cells, and due to the shift of non-CSCs to the CSC state. For example, in glioblastoma exposure of differentiated non-CSCs to 
temozolomide (TZM) resulted in re-expression of stem cell markers such as SOX2, OCT4 and Nestin, which in turn lead further expansion of CSCs [81]. Therefore, acquisition of therapeutic resistance may be a dynamic and reversible process, and under therapeutic pressure, cells can switch between the drug-resistant and drug-sensitive states. Also, resistance against therapies is gained through promoting the acquisition of a de-differentiated state by increasing the expression of stemness-related genes [82-83].

Additionally, trans-differentiation is another mechanism of cellular plasticity associated with resistance to therapy [84-85]. For instance, in advanced prostate adenocarcinoma, androgen deprivation therapy can ultimately lead to resistance and progression of aggressive phenotypes, which manifests phenotypic and molecular characteristics of neuroendocrine differentiation [84-85].

Tumour microenvironment could add fuel to the therapy resistance property of CSCs [86-88]. Local signals from tumour microenvironment influence the generation of several drug-tolerant phenotypes such as EMT and CSC-like states in region-specific manner in tumour. For example, TGF $\beta$, IL-6, exosomes, and many other cancer-associated fibroblasts (CAF)-secreted cytokines as well as growth factors have been identified to push the formation of drug-resistant EMT phenotypes in the heavily localized CAFs invasive tumour front [86-88]. Likewise, hypoxia can induce therapeutic resistance by creating a signalling network favourable to drug-tolerant EMT states [89]. Therefore, in the notion of therapy resistance, plasticity of CSCs plays a pivotal role. To ensure the proper therapeutic outcome in clinical settings, newly designed drug must have the ability to escape or diminish this dynamic property of CSCs. 


\section{Therapeutic options against plasticity of CSCs}

Development of treatment strategies targeting directly the dynamic and plastic behaviour of CSCs can have attractive therapeutic potential. From the therapeutic standpoint, plasticity of cancer cells always creates problems as the presence of multiple phenotypes within a single tumour always holds the risk that a given therapy will fail to kill some of the tumour cells [90]. Therefore, greater efforts should be taken, firstly by understanding the origin of diversity of the tumour and then, by exploiting that knowledge to design novel therapy. Table 2 represents the potential therapeutic options targeting plasticity of CSC.

Presently, several clinical strategies have been proposed that could be effective against plasticity of CSCs. Firstly, therapeutics blocking or reversing de-differentiation of CSCs as they could be generated de novo by dedifferentiation of non-CSCs, which prevent cancer cells from becoming metastatic and developing drug-resistant phenotype [90]. Secondly, therapeutics could be beneficial to patients by neutralization the factors associated with the promotion of EMT. Thirdly, treatment can be targeted by blocking the signalling pathway used by EMT cells to evade, survive in the circulation, or resist therapy against cancer. Thus, it is critical to destroy cancer cells that undergo EMT to not only block or reverse that process. Interestingly, various approaches have already been taken to combat signalling pathways that induce EMT such as TGF- $\beta$, STAT3, miR-210 [91-94]. Importantly, additional research might be required to justify the efficacy of these strategies with respect to their specificity to CSCs in vivo. Subsequently, as cellular plasticity is involved with partial EMT, it will be necessary to test the efficacy of these new strategies targeting hybrid epithelial/mesenchymal cells [95].

In addition, hedgehog signalling plays a significant role in cancer-associated fibroblasts (CAFs), thereby acting as a novel mediator of CSC plasticity and opens up a doorway of exciting new therapeutic target in triple-negative breast carcinoma [96]. 
Hedgehog ligand produced by neoplastic cells in mouse models, reprograms CAFs to confer a supportive niche for the accumulation of chemo-resistant CSC phenotype via FGF5 expression [96]. Accordingly, stromal treatment with smoothened inhibitors (SMOi) impedes CSC markers expression and sensitizes tumour cells to docetaxel, leading to markedly improved patients' survival and reduction of metastatic burden of cancer [96]. In a phase-I clinical trial (NCT02027376), 3 out of 12 patients with metastatic triple-negative breast carcinoma obtained clinical benefit from combination therapy with SMOi, Sonidegib and docetaxel [96].

Targeting metabolic plasticity of CSCs has become an emerging area to effective elimination of CSCs. To inhibit glycolysis in CSCs, glucose transporter and glycolytic enzymes such as GLUT1-4, hexokinase1-2, pyruvate kinase M2, and lactate dehydrogenase have been proposed as attractive targets [97-99]. Moreover, mitochondrial metabolism could be a useful target to eliminate OXPHOS phenotype of CSC in numerous cancers $[60,100$ 101]. Targeting CSCs through inhibition of mitochondrial biogenesis and OXPHOS are currently under investigation for cancer treatment. For instance, salinomycin, erythromycins, tetracyclines, and glycylcyclines have already demonstrated efficacy in eradicating CSCs via blocking the plasticity of CSCs [101-104]. Another compound, metformin, an inhibitor of OXPHOS complex-I has demonstrated anti-cancer activity by reducing mammosphere formation, in vivo tumour growth, and inducing apoptosis in pancreatic CSCs via preventing metabolic switch to glycolysis [60, 105-106]. Since CSCs can also expose intermediate glycolytic/ OXPHOS phenotype, therefore treatment option targeting this intermediate phenotype could be effective in eradicating CSCs. Interestingly, mitochondrial reactive oxygen species (ROS) inducer such as menadione could prevent or reverse glycolytic/ OXPHOS phenotype [101]. Dual mechanism of menadione inhibition of Complex-I, and induction of mitochondrial ROS points out the significant efficacy of multi-modal targeted 
therapy. Moreover, inhibiting mitochondrial respiration not only induces apoptosis in pancreatic CSCs with OXPHOS phenotype but also effectively eliminates primarily glycolytic breast and nasopharyngeal CSCs [60, 107].

Another potential target is the inhibition of adaptive mechanism of CSC. It was noted that under heterogeneous environmental condition such as hypoxia, glucose deprivation, and low $\mathrm{pH}, \mathrm{CSC}$ rapidly transits their metabolism and this adaptive metabolic switch by CSCs play a pivotal role in cancer metastasis or chemo-resistance [108]. There are several factors or enzymes involved in the metabolic adaptation of CSCs, which are sensitive to specific therapeutic actions. For example, HIF1-2 alpha is a key enzyme for metabolic adaptation in hypoxia and is associated with angiogenesis, metastasis, and cell survival [108].

Interestingly, there are some potential compounds such as TH-302, a nitroimidazole prodrug of the DNA alkylating agent in combination with doxorubicin, has been found effective against HIF in soft tissue sarcoma [109]. Another enzyme pyruvate dehydrogenase kinase 1 is enriched in breast CSCs and is critical for metastasis in hypoxia. Pyruvate dehydrogenase kinase 1 regulates the metabolic transition in hypoxia via controlling the amount of acetylCoA, which is oxidized in the mitochondria to produce energy in the TCA cycle [110]. Anticancer agent from Cinnamomum cassia Blume targets pyruvate dehydrogenase kinase 1 and induces mitochondria-mediated apoptosis in lung carcinoma stem cells [111].

Conventional chemo-radiotherapies are not effective against quiescent, slowly (or non-) dividing CSCs, thereby become resistant and subsequently repopulate the tumour [112]. Interestingly, it was found that a compound named thapsigargin targets highly plastic CSCs in a proliferation independent fashion and can thus effectively target quiescent cells [113-114]. However, thapsigargin is not selective for cancer cells, but recent efforts to modify it as a tumour-targeted pro-drug have greatly improved the specificity profile and undergoing phase II trials (NCT01056029) [115]. 
Epigenetic regulators, another potential class of therapeutic targets, could be conducive in regulating cell state plasticity [116-117]. For example, histone-deacetylase inhibitors (e.g. suberoylanilide hydroxamic acid, abexinostat) have been shown to promote differentiation of breast cancer cells and diminish the number of CSCs within cancer [116117]. Moreover, a key feature of epigenetic mechanisms is their inherent reversibility, which helps cancer cells to gain cellular plasticity. This dependence of CSCs on epigenetic regulators offers an opportunity to target their self-renewal capacity. Overall, the concept of CSC plasticity is new and aiming drivers of plasticity mechanisms carries the future promise. Thus, further studies to identify and target drivers of CSC plasticity are imperative.

\section{Concluding remarks}

The present review discusses the critical insights regarding the plasticity of CSCs, emphasizing the mechanism through which CSCs acquire the phenotype. The phenomena such as program development, metabolic adaptation, epigenetic changes attribution in CSC's plasticity are highlighted. It is observed that phenotypic plasticity is directly associated with cellular origins of cancer as well as the progression of cancer and response to therapy. Moreover, it is important to apply the principles of targeting phenotypic plasticity as an anticancer target. If so, they may give rise to unexpected vulnerabilities that can be exploited to target cancer cells. Relevant factors driving the switch from hierarchy to plasticity are getting the attention to inhibit the plastic behaviour of cancer cells, especially of CSCs. In that case, inhibition of deregulated transcription factors, that regulate the normal cell differentiation as well as CSC, might be an attractive option. Therefore, targeting the sources for phenotypic plasticity in cancer cells, for instance, suppression of oncogenes and/or modification of tumour microenvironment can contribute to the reduction of CSC's plasticity. However, it is clear that CSCs occupy their plasticity by different mechanisms such as 
microenvironmental signals, metabolic adaptations, epigenetic alterations etc. Since tumour cells maintain a network of changes in case of their progression, therefore targeting or inhibiting one property could boost others. Thus, to inhibit or stop plastic behaviour of CSCs focus should be set on combined targets or more directed therapies that could aim for more than one property of CSCs at a time.

Conflict of interest: Authors have no conflict of interest.

Acknowledgement: The project was supported by the new staff start-up funding, Faculty of Medicine, The University of Queensland, Queensland, Australia. 


\section{Reference}

1. Gupta, P. B., Pastushenko, I., Skibinski, A., Blanpain, C., \& Kuperwasser, C. (2018).

Phenotypic plasticity: driver of cancer initiation, progression, and therapy resistance. Cell Stem Cell, 24, 65-78. doi: 10.1016/j.stem.2018.11.011.

2. Nowell, P. C. (1976). The clonal evolution of tumor cell populations. Science, 194, 23-28.

3. Cabrera, M. C., Hollingsworth, R. E., \& Hurt, E. M. (2015). Cancer stem cell plasticity and tumor hierarchy. World journal of stem cells, 7, 27. doi:10.4252/wjsc.v7.i1.27.

4. Morel, A. P., Lièvre, M., Thomas, C., Hinkal, G., Ansieau, S., \& Puisieux, A. (2008).

Generation of breast cancer stem cells through epithelial-mesenchymal transition. PloS one, 3, e2888.

5. Mani, S. A., Guo, W., Liao, M. J., Eaton, E.N., Ayyanan, A., Zhou, A. Y., Brooks, M., Reinhard, F., Zhang, C. C., Shipitsin, M., Campbell, L.L., Polyak, K., Brisken, C., Yang, J., Weinberg, R. A. (2008). The epithelial mesenchymal transition generates cells with properties of stem cells. Cell, 133, 704-715. doi: 10.1016/j.cell.2008.03.027.

6. Ahmed, F., \& Haass, N. K. (2018). Microenvironment-driven dynamic heterogeneity and phenotypic plasticity as a mechanism of melanoma therapy resistance. Frontiers in oncology, 8, 173. doi: 10.3389/fonc.2018.00173.

7. Davies, A. E., \& Albeck, J. G. (2018). Microenvironmental signals and biochemical information processing: cooperative determinants of intratumoral plasticity and heterogeneity. Frontiers in cell and developmental biology, 6, 44. doi:10.3389/fcell.2018.00044.

8. Greaves, M. (2015). Evolutionary determinants of cancer. Cancer discovery, 5(8), 806820.doi: 10.1158/2159-8290.CD-15-0439. 
9. Williams, M. J., Werner, B., Barnes, C. P., Graham, T. A., \& Sottoriva, A. (2016). Identification of neutral tumor evolution across cancer types. Nature genetics, 48(3), 238244. doi: $10.1038 / \mathrm{ng} .3489$.

10. Ahmed, N., Escalona, R., Leung, D., Chan, E., \& Kannourakis, G. (2018). Tumour microenvironment and metabolic plasticity in cancer and cancer stem cells: Perspectives on metabolic and immune regulatory signatures in chemoresistant ovarian cancer stem cells. Semin Cancer Biol, 53, 265-281. doi:10.1016/j.semcancer.2018.10.002.

11. Wainwright, E. N., Scaffidi, P. (2017). Epigenetics and Cancer Stem Cells: Unleashing, Hijacking, and Restricting Cellular Plasticity. Trends Cancer, 3(5), 372-386.doi: 10.1016/j.trecan.2017.04.004.

12. Green, S. A., Simoes-Costa, M., \& Bronner, M. E. (2015). Evolution of vertebrates as viewed from the crest. Nature, 520(7548), 474-482. doi: 10.1038/nature14436.

13. Burrell, R. A., McGranahan, N., Bartek, J., Swanton, C. (2013). The causes and consequences of genetic heterogeneity in cancer evolution. Nature, 501(7467), 338-45. doi: 10.1038 /nature 12625

14. Ombrato, L., Malanchi, I. (2014). The EMT universe: space between cancer cell dissemination and metastasis initiation. Critical Reviews ${ }^{\text {TM }}$ in Oncogenesis, 19(5), 349-61. 15. Brooks, M. D., Burness, M. L., \& Wicha, M. S. (2015). Therapeutic implications of cellular heterogeneity and plasticity in breast cancer. Cell stem cell, 17(3), 260-271.doi: 10.1016/j.stem.2015.08.014.

16. Thiery, J. P., \& Sleeman, J. P. (2006). Complex networks orchestrate epithelialmesenchymal transitions. Nature reviews Molecular cell biology, 7(2), 131-42.

17. Puisieux, A., Pommier, R. M., Morel, A. P., \& Lavial, F. (2018). Cellular pliancy and the multistep process of tumorigenesis. Cancer cell, 33(2), 164-172. 
18. Brabletz, T., Jung, A., Spaderna, S., Hlubek, F., \& Kirchner, T. (2005). Migrating cancer stem cells - an integrated concept of malignant tumour progression. Nature Reviews Cancer, 5(9), 744.

19. Kalcheim, C. (2016). Epithelial-mesenchymal transitions during neural crest and somite development. Journal of clinical medicine, 5(1), 1. doi: 10.3390/jcm5010001.

20. Latil, M., Nassar, D., Beck, B., Boumahdi, S., Wang, L., Brisebarre, A., ...\& Drubbel, A. V. (2017). Cell-type-specific chromatin states differentially prime squamous cell carcinoma tumor-initiating cells for epithelial to mesenchymal transition. Cell stem cell, 20(2), 191-204. doi: 10.1016/j.stem.2016.10.018.

21. Hemavathy, K., Guru, S. C., Harris, J., Chen, J. D., \& Ip, Y. T. (2000). Human Slug is a repressor that localizes to sites of active transcription. Molecular and cellular biology, 20(14), 5087-5095.

22. Isaac, A., Sargent, M. G., \& Cooke, J. (1997). Control of vertebrate left-right asymmetry by a snail-related zinc finger gene. Science, 275(5304), 1301-1304.

23. Nieto, M. A. (2002). The snail superfamily of zinc-finger transcription factors. Nature reviews Molecular cell biology, 3(3), 155-66.

24. Krebs, A. M., Mitschke, J., Losada, M. L., Schmalhofer, O., Boerries, M., Busch, H., ...\& Brunton, V. G. (2017). The EMT-activator Zeb1 is a key factor for cell plasticity and promotes metastasis in pancreatic cancer. Nature cell biology, 19(5), 518-529. doi: 10.1038/ncb3513.

25. Tata, P. R., Chow, R. D., Saladi, S. V., Tata, A., Konkimalla, A., Bara, A., ... \& Mou, H. (2018). Developmental history provides a roadmap for the emergence of tumor plasticity. Developmental cell, 44(6), 679-693.doi: 10.1016/j.devcel.2018.02.024.

26. Balkwill, F. R., Capasso, M., \& Hagemann, T. (2012). The tumor microenvironment at a glance, 125(Pt 23), 5591-6. doi: 10.1242/jcs.116392. 
27. Junttila, M. R., \& de Sauvage, F. J. (2013). Influence of tumour micro-environment heterogeneity on therapeutic response. Nature, 501(7467), 346. doi: 10.1038/nature12626. 28. Vermeulen, L., Felipe De Sousa, E. M., Van Der Heijden, M., Cameron, K., De Jong, J. H., Borovski, T., ...\& Sprick, M. R. (2010). Wnt activity defines colon cancer stem cells and is regulated by the microenvironment. Nature cell biology, 12(5), 468. doi: $10.1038 / \mathrm{ncb} 2048$.

29. Cabrera, M. C., Tilahun, E., Nakles, R., Diaz-Cruz, E. S., Charabaty, A., Suy, S., ...\& Collins, S. P. (2014). Human pancreatic cancer-associated stellate cells remain activated after in vivo chemoradiation. Frontiers in oncology, 4, 102.doi:10.3389/fonc.2014.00102. 30. Mantoni, T. S., Lunardi, S., Al-Assar, O., Masamune, A., \& Brunner, T. B. (2011). Pancreatic stellate cells radioprotect pancreatic cancer cells through $\beta 1$-integrin signaling. Cancer research, 71(10), 3453-3458.doi: 10.1158/0008-5472.CAN-10-1633. 31. Tang, D., Wang, D., Yuan, Z., Xue, X., Zhang, Y., An, Y., ...\& Jiang, K. (2013). Persistent activation of pancreatic stellate cells creates a microenvironment favorable for the malignant behavior of pancreatic ductal adenocarcinoma. International journal of cancer, 132(5), 993-1003. doi: 10.1002/ijc.27715.

32. Hamada, S., Masamune, A., Takikawa, T., Suzuki, N., Kikuta, K., Hirota, M., ...\& Shimosegawa, T. (2012). Pancreatic stellate cells enhance stem cell-like phenotypes in pancreatic cancer cells. Biochemical and biophysical research communications, 421(2), 349354.doi: 10.1016/j.bbrc.2012.04.014.

33. Lonardo, E., Frias-Aldeguer, J., Hermann, P. C., \& Heeschen, C. (2012). Pancreatic stellate cells form a niche for cancer stem cells and promote their self-renewal and invasiveness. Cell cycle, 11(7), 1282-1290.doi: 10.4161/cc.19679. 
34. Hanahan, D., \& Coussens, L. M. (2012). Accessories to the crime: functions of cells recruited to the tumor microenvironment. Cancer cell, 21(3), 309-322.doi:

10.1016/j.ccr.2012.02.022.

35. Plaks, V., Kong, N., \& Werb, Z. (2015). The cancer stem cell niche: how essential is the niche in regulating stemness of tumor cells?. Cell stem cell, 16(3), 225-238.doi:

10.1016/j.stem.2015.02.015.

36. Yi, S. Y., Hao, Y. B., Nan, K. J., \& Fan, T. L. (2013). Cancer stem cells niche: a target for novel cancer therapeutics. Cancer Treatment Reviews, 39(3), 290-296.doi:

10.1074/jbc.R117.799973.

37. Qian, J., \& Rankin, E. B. (2019). Hypoxia-Induced Phenotypes that Mediate Tumor Heterogeneity. In Hypoxia and Cancer Metastasis (pp. 43-55). Springer, Cham. doi: 10.1007/978-3-030-12734-3_3.

38. Gentric, G., Mieulet, V., \& Mechta-Grigoriou, F. (2017). Heterogeneity in cancer metabolism: new concepts in an old field. Antioxidants \& Redox Signaling, 26(9), 462485.doi: 10.1089/ars.2016.6750.

39. McGranahan, N., \& Swanton, C. (2017). Clonal heterogeneity and tumor evolution: past, present, and the future. Cell, 168(4), 613-628.doi: 10.1016/j.cell.2017.01.018.

40. Tsai, Y. P., \& Wu, K. J. (2012). Hypoxia-regulated target genes implicated in tumor metastasis. Journal of biomedical science, 19(1), 102. doi: 10.1186/1423-0127-19-102. 41. Li, Z., Bao, S., Wu, Q., Wang, H., Eyler, C., Sathornsumetee, S., ...\& Hjelmeland, A. B. (2009). Hypoxia-inducible factors regulate tumorigenic capacity of glioma stem cells. Cancer cell, 15(6), 501-513.doi: 10.1016/j.ccr.2009.03.018.

42. Abyaneh, H. S., Gupta, N., Alshareef, A., Gopal, K., Lavasanifar, A., \& Lai, R. (2018). Hypoxia induces the Acquisition of Cancer Stem-like Phenotype via Upregulation and Activation of signal transducer and activator of Transcription-3 (STAT3) in MDA-MB-231, a 
triple negative breast Cancer cell line. Cancer Microenvironment, 11(2-3), 141-152.doi: $10.1007 / \mathrm{s} 12307-018-0218-0$.

43. Choi, H. Y., Yang, G. M., Dayem, A. A., Saha, S. K., Kim, K., Yoo, Y., ... \& Cho, S. G. (2019). Hydrodynamic shear stress promotes epithelial-mesenchymal transition by downregulating ERK and GSK3 $\beta$ activities. Breast Cancer Research, 21(1), 6.doi: 10.1186/s13058-018-1071-2.

44. Haass, N. K., Beaumont, K. A., Hill, D. S., Anfosso, A., Mrass, P., Munoz, M. A., ... \& Weninger, W. (2014). Real-time cell cycle imaging during melanoma growth, invasion, and drug response. Pigment cell \& melanoma research, 27(5), 764-776. doi:10.1111/pcmr.12274. 45. Snyder, V., Reed-Newman, T. C., Arnold, L., Thomas, S. M., \& Anant, S. (2018). Cancer stem cell metabolism and potential therapeutic targets. Frontiers in oncology, 8 , 203.doi:10.3389/fonc.2018.00203.

46. Sancho, P., Barneda, D., \& Heeschen, C. (2016). Hallmarks of cancer stem cell metabolism. British journal of cancer, 114(12), 1305-12. doi: 10.1038/bjc.2016.152. 47. Folmes, C. D., Dzeja, P. P., Nelson, T. J., \& Terzic, A. (2012). Metabolic plasticity in stem cell homeostasis and differentiation. Cell stem cell, 11(5), 596-606.doi: 10.1016/j.stem.2012.10.002.

48. Ciavardelli, D., Rossi, C., Barcaroli, D., Volpe, S., Consalvo, A., Zucchelli, M., ...\& Forli, F. (2014). Breast cancer stem cells rely on fermentative glycolysis and are sensitive to 2-deoxyglucose treatment. Cell death \& disease, 5(7), e1336. doi: 10.1038/cddis.2014.285. 49. Liao, J., Qian, F., Tchabo, N., Mhawech-Fauceglia, P., Beck, A., Qian, Z., ...\& Odunsi, K. (2014). Ovarian cancer spheroid cells with stem cell-like properties contribute to tumor generation, metastasis and chemotherapy resistance through hypoxia-resistant metabolism. PloS one, 9(1), e84941. doi: 10.1371/journal.pone.0084941. 
50. Palorini, R., Votta, G., Balestrieri, C., Monestiroli, A., Olivieri, S., Vento, R., \& Chiaradonna, F. (2014). Energy Metabolism Characterization of a Novel Cancer Stem Cell-L ike Line 3 AB-OS. Journal of cellular biochemistry, 115(2), 368-379. doi:10.1002/jcb.24671. 51. Zhou, Y., Zhou, Y., Shingu, T., Feng, L., Chen, Z., Ogasawara, M., ...\& Huang, P. (2011). Metabolic alterations in highly tumorigenic glioblastoma cells preference for hypoxia and high dependency on glycolysis. Journal of Biological Chemistry, 286(37), 3284332853.doi: 10.1074/jbc.M111.260935.

52. Chen, K. Y., Liu, X., Bu, P., Lin, C. S., Rakhilin, N., Locasale, J. W., \& Shen, X. (2014, August). A metabolic signature of colon cancer initiating cells. In 2014 36th Annual International Conference of the IEEE Engineering in Medicine and Biology Society (pp. 4759-4762). IEEE. doi: 10.1109/EMBC.2014.6944688.

53. Wu, M., Neilson, A., Swift, A. L., Moran, R., Tamagnine, J., Parslow, D., ...\& Chomicz, S. (2007). Multiparameter metabolic analysis reveals a close link between attenuated mitochondrial bioenergetic function and enhanced glycolysis dependency in human tumor cells. American Journal of Physiology-Cell Physiology, 292(1), C125-C136.

54. Liu, P. P., Liao, J., Tang, Z. J., Wu, W. J., Yang, J., Zeng, Z. L., ... \& Huang, P. (2014). Metabolic regulation of cancer cell side population by glucose through activation of the Akt pathway. Cell death and differentiation, 21(1), 124. doi: 10.1038/cdd.2013.131.

55. Kondoh, H., Lleonart, M. E., Gil, J., Wang, J., Degan, P., Peters, G.,...\& Beach, D. (2005). Glycolytic enzymes can modulate cellular life span. Cancer research, 65(1), 177185.

56. Demaria, M., Giorgi, C., Lebiedzinska, M., Esposito, G., D'Angeli, L., Bartoli, A., ...\& Wieckowski, M. R. (2010). A STAT3-mediated metabolic switch is involved in tumour transformation and STAT3 addiction. Aging (Albany NY), 2(11), 823. 
57. Chan, E., Luwor, R., Burns, C., Kannourakis, G., Findlay, J. K., \& Ahmed, N. (2018). Momelotinib decreased cancer stem cell associated tumor burden and prolonged disease-free remission period in a mouse model of human ovarian cancer. Oncotarget, 9(24), 1659916618. doi: 10.18632/oncotarget.24615.

58. Vlashi, E., Lagadec, C., Vergnes, L., Matsutani, T., Masui, K., Poulou, M., ...\& Reue, K. (2011). Metabolic state of glioma stem cells and nontumorigenic cells. Proceedings of the National Academy of Sciences, 108(38), 16062-16067.doi: 10.1073/pnas.1106704108. 59. Janiszewska, M., Suvà, M. L., Riggi, N., Houtkooper, R. H., Auwerx, J., ClémentSchatlo, V., ...\& Stamenkovic, I. (2012). Imp2 controls oxidative phosphorylation and is crucial for preserving glioblastoma cancer stem cells. Genes \& development, 26(17), 19261944. doi: 10.1101/gad.188292.112.

60. Sancho, P., Burgos-Ramos, E., Tavera, A., Kheir, T. B., Jagust, P., Schoenhals, M., ...\& Viera, C. R. (2015). MYC/PGC-1 $\alpha$ balance determines the metabolic phenotype and plasticity of pancreatic cancer stem cells. Cell metabolism, 22(4), 590-605. doi: 10.1016/j.cmet.2015.08.015.

61. De Francesco, E. M., Sotgia, F., \& Lisanti, M. P. (2018). Cancer stem cells (CSCs): metabolic strategies for their identification and eradication. Biochemical Journal, 475(9), 1611-1634. doi: 10.1042/BCJ20170164.

62. Zhang, D., Wang, Y., Shi, Z., Liu, J., Sun, P., Hou, X., ...\& Mi, J. (2015). Metabolic reprogramming of cancer-associated fibroblasts by IDH3 $\alpha$ downregulation. Cell reports, 10(8), 1335-1348.doi: 10.1016/j.celrep.2015.02.006.

63. Keith, B., \& Simon, M. C. (2007). Hypoxia-inducible factors, stem cells, and cancer. Cell, 129(3), 465-472. 
64. Bhowmik, S. K., Ramirez-Peña, E., Arnold, J. M., Putluri, V., Sphyris, N., Michailidis, G., ...\& Mani, S. A. (2015). EMT-induced metabolite signature identifies poor clinical outcome. Oncotarget, 6(40), 42651.doi: 10.18632/oncotarget.4765.

65. Aguilar, E., Marin de Mas, I., Zodda, E., Marin, S., Morrish, F., Selivanov, V., ...\& CeliàTerrassa, T. (2016). Metabolic reprogramming and dependencies associated with epithelial cancer stem cells independent of the epithelial-mesenchymal transition program. Stem Cells, 34(5), 1163-1176.doi: 10.1002/stem.2286.

66. Chen, E. I., Hewel, J., Krueger, J. S., Tiraby, C., Weber, M. R., Kralli, A., ... \& FeldingHabermann, B. (2007). Adaptation of energy metabolism in breast cancer brain metastases. Cancer research, 67(4), 1472-1486.

67. Sosa, M. S., Bragado, P., \& Aguirre-Ghiso, J. A. (2014). Mechanisms of disseminated cancer cell dormancy: an awakening field. Nature Reviews Cancer, 14(9), 611.doi: $10.1038 / \mathrm{nrc} 3793$.

68. Chaffer, C. L., Marjanovic, N. D., Lee, T., Bell, G., Kleer, C. G., Reinhardt, F., ...\& Weinberg, R. A. (2013). Poised chromatin at the ZEB1 promoter enables breast cancer cell plasticity and enhances tumorigenicity. Cell, 154(1), 61-74.doi: 10.1016/j.cell.2013.06.005. 69. Quintana, E., Shackleton, M., Sabel, M. S., Fullen, D. R., Johnson, T. M., \& Morrison, S. J. (2008). Efficient tumour formation by single human melanoma cells. Nature, 456(7222), 593.doi: 10.1038/nature07567.

70. Roesch, A., Fukunaga-Kalabis, M., Schmidt, E. C., Zabierowski, S. E., Brafford, P. A., Vultur, A.,...\& Herlyn, M. (2010). A temporarily distinct subpopulation of slow-cycling melanoma cells is required for continuous tumor growth. Cell, 141(4), 583-594.doi: 10.1016/j.cell.2010.04.020. 
71. Cancer Genome Atlas Research Network. (2013). Genomic and epigenomic landscapes of adult de novo acute myeloid leukemia. New England Journal of Medicine, 368(22), 20592074.doi: 10.1056/NEJMoa1301689.

72. Kim, M. S., Kim, Y. R., Yoo, N. J., \& Lee, S. H. (2013). Mutational analysis of DNMT3A gene in acute leukemias and common solid cancers. Apmis, 121(2), 85-94.doi: $10.1111 / \mathrm{j} .1600-0463.2012 .02940$

73. Cohen, A. L., Holmen, S. L., \& Colman, H. (2013). IDH1 and IDH2 mutations in gliomas. Current neurology and neuroscience reports, 13(5), 345. doi: 10.1007/s11910-013$0345-4$.

74. Arienti, C., Zanoni, M., Pignatta, S., Del Rio, A., Carloni, S., Tebaldi, M., ...\& Tesei, A. (2016). Preclinical evidence of multiple mechanisms underlying trastuzumab resistance in gastric cancer. Oncotarget, 7(14), 18424. doi: 10.18632/oncotarget.7575.

75. Chang, A. (2011). Chemotherapy, chemoresistance and the changing treatment landscape for NSCLC. Lung cancer, 71(1), 3-10. doi: 10.1016/j.lungcan.2010.08.022.

76. Haslehurst, A. M., Koti, M., Dharsee, M., Nuin, P., Evans, K., Geraci, J., ...\& Davey, S. (2012). EMT transcription factors snail and slug directly contribute to cisplatin resistance in ovarian cancer. BMC cancer, 12(1), 91.doi: 10.1186/1471-2407-12-91.

77. Gupta, P. B., Onder, T. T., Jiang, G., Tao, K., Kuperwasser, C., Weinberg, R. A., \& Lander, E. S. (2009). Identification of selective inhibitors of cancer stem cells by highthroughput screening. cell, 138(4), 645-659.doi: 10.1016/j.cell.2009.06.034.

78. Abdullah, L. N., \& Chow, E. K. H. (2013). Mechanisms of chemoresistance in cancer stem cells. Clinical and translational medicine, 2(1), 3. doi: 10.1186/2001-1326-2-3. 79. Zhang, P., Wei, Y., Wang, L., Debeb, B. G., Yuan, Y., Zhang, J., ... \& Woodward, W. A. (2014). ATM-mediated stabilization of ZEB1 promotes DNA damage response and radioresistance through CHK1. Nature cell biology, 16(9), 864-75. doi: 10.1038/ncb3013. 
80. Creighton, C. J., Li, X., Landis, M., Dixon, J. M., Neumeister, V. M., Sjolund, A., ...\& Fan, C. (2009). Residual breast cancers after conventional therapy display mesenchymal as well as tumor-initiating features. Proceedings of the National Academy of Sciences, 106(33), 13820-13825. doi: 10.1073/pnas.0905718106.

81. Auffinger, B., Tobias, A. L., Han, Y., Lee, G., Guo, D., Dey, M., ...\& Ahmed, A. U. (2014). Conversion of differentiated cancer cells into cancer stem-like cells in a glioblastoma model after primary chemotherapy. Cell death and differentiation, 21(7), 1119.doi: 10.1038/cdd.2014.31.

82. Kurrey, N. K., Jalgaonkar, S. P., Joglekar, A. V., Ghanate, A. D., Chaskar, P. D., Doiphode, R. Y., \& Bapat, S. A. (2009). Snail and slug mediate radioresistance and chemoresistance by antagonizing p53-mediated apoptosis and acquiring a stem-like phenotype in ovarian cancer cells. Stem cells, 27(9), 2059-2068.doi: 10.1002/stem.154. 83. Del Vecchio, C. A., Feng, Y., Sokol, E. S., Tillman, E. J., Sanduja, S., Reinhardt, F., \& Gupta, P. B. (2014). De-differentiation confers multidrug resistance via noncanonical PERKNrf2 signaling. PLoS biology, 12(9), e1001945.doi:10.1371/journal.pbio.1001945. 84. Watson, P. A., Arora, V. K., \& Sawyers, C. L. (2015). Emerging mechanisms of resistance to androgen receptor inhibitors in prostate cancer. Nature Reviews Cancer, 15(12), 701.doi: $10.1038 / \mathrm{nrc} 4016$.

85. Davies, A. H., Beltran, H., \& Zoubeidi, A. (2018). Cellular plasticity and the neuroendocrine phenotype in prostate cancer. Nature Reviews Urology, 15(5), 271.doi: 10.1038/nrurol.2018.22.

86. Yamada, D., Kobayashi, S., Wada, H., Kawamoto, K., Marubashi, S., Eguchi, H., ...\& Mori, M. (2013). Role of crosstalk between interleukin-6 and transforming growth factorbeta 1 in epithelial-mesenchymal transition and chemoresistance in biliary tract cancer. European journal of cancer, 49(7), 1725-1740. 
87. Boelens, M. C., Wu, T. J., Nabet, B. Y., Xu, B., Qiu, Y., Yoon, T., ... \& Ter Brugge, P. J. (2014). Exosome transfer from stromal to breast cancer cells regulates therapy resistance pathways. Cell, 159(3), 499-513.doi: 10.1016/j.cell.2014.09.051.

88. Yu, Y., Xiao, C. H., Tan, L. D., Wang, Q. S., Li, X. Q., \& Feng, Y. M. (2014). Cancerassociated fibroblasts induce epithelial-mesenchymal transition of breast cancer cells through paracrine TGF- $\beta$ signalling. British journal of cancer, 110(3), 724-32. doi: 10.1038/bjc.2013.768.

89. Joseph, J. P., Harishankar, M. K., Pillai, A. A., \& Devi, A. (2018). Hypoxia induced EMT: a review on the mechanism of tumor progression and metastasis in OSCC. Oral oncology, 80, 23-32.doi: 10.1016/j.oraloncology.2018.03.004.

90. Smigiel, J., Parameswaran, N., \& Jackson, M. (2018). Targeting pancreatic cancer cell plasticity: the latest in therapeutics. Cancers, 10(1), 14. doi: 10.3390/cancers10010014. 91. Nieto, M. A., Huang, R. Y. J., Jackson, R. A., \& Thiery, J. P. (2016). EMT: 2016. Cell, 166(1), 21-45. doi: 10.1016/j.cell.2016.06.028. 92. Kaur, G., Sharma, P., Dogra, N., \& Singh, S. (2018). Eradicating cancer stem cells: concepts, issues, and challenges. Current treatment options in oncology, 19(4), 20. doi:10.1007/s11864-018-0533-1.

93. Cai, Z., Cao, Y., Luo, Y., Hu, H., \& Ling, H. (2018). Signalling mechanism (s) of epithelial-mesenchymal transition and cancer stem cells in tumour therapeutic resistance. Clinica Chimica Acta, 483, 156-163. doi: 10.1016/j.cca.2018.04.033. 94. Smith, A. L., Robin, T. P., \& Ford, H. L. (2012). Molecular pathways: targeting the TGF$\beta$ pathway for cancer therapy. Clinical Cancer Research, 18(17), 45144521.doi:10.1158/1078-0432.CCR-11-3224. 
95. Santamaria, P. G., Moreno-Bueno, G., Portillo, F., \& Cano, A. (2017). EMT: Present and future in clinical oncology. Molecular oncology, 11(7), 718-738. doi:10.1002/18780261.12091.

96. Cazet, A. S., Hui, M. N., Elsworth, B. L., Wu, S. Z., Roden, D., Chan, C. L., ... \& Johan, M. Z. (2018). Targeting stromal remodeling and cancer stem cell plasticity overcomes chemoresistance in triple negative breast cancer. Nature communications, 9(1), 2897. doi:10.1038/s41467-018-05220-6.

97. Annibaldi, A., \& Widmann, C. (2010). Glucose metabolism in cancer cells. Current Opinion in Clinical Nutrition \& Metabolic Care, 13(4), 466-470. doi:

10.1097/MCO.0b013e32833a5577.

98. Krasnov, G. S., Dmitriev, A. A., Snezhkina, A. V., \& Kudryavtseva, A. V. (2013). Deregulation of glycolysis in cancer: glyceraldehyde-3-phosphate dehydrogenase as a therapeutic target. Expert opinion on therapeutic targets, 17(6), 681-693.doi: $10.1517 / 14728222.2013 .775253$.

99. Ceradini, D. J., Kulkarni, A. R., Callaghan, M. J., Tepper, O. M., Bastidas, N., Kleinman, M. E., ... \& Gurtner, G. C. (2004). Progenitor cell trafficking is regulated by hypoxic gradients through HIF-1 induction of SDF-1. Nature medicine, 10(8), 858.

100. Roesch, A., Vultur, A., Bogeski, I., Wang, H., Zimmermann, K. M., Speicher, D., ...\& Krause, E. (2013). Overcoming intrinsic multidrug resistance in melanoma by blocking the mitochondrial respiratory chain of slow-cycling JARID1Bhigh cells. Cancer cell, 23(6), 811825. doi: 10.1016/j.ccr.2013.05.003.

101. Lamb, R., Ozsvari, B., Lisanti, C. L., Tanowitz, H. B., Howell, A., MartinezOutschoorn, U. E., ... \& Lisanti, M. P. (2015). Antibiotics that target mitochondria effectively eradicate cancer stem cells, across multiple tumor types: treating cancer like an infectious disease. Oncotarget, 6(7), 4569-84. 
102. Lamb, R., Harrison, H., Hulit, J., Smith, D. L., Lisanti, M. P., \& Sotgia, F. (2014). Mitochondria as new therapeutic targets for eradicating cancer stem cells: Quantitative proteomics and functional validation via MCT1/2 inhibition. Oncotarget, 5(22), 11029-37. 103. An, H., Kim, J. Y., Oh, E., Lee, N., Cho, Y., \& Seo, J. H. (2015). Salinomycin promotes anoikis and decreases the CD44+/CD24-stem-like population via inhibition of STAT3 activation in MDA-MB-231 cells. PLoS One, 10(11), e0141919.doi: 10.1371/journal.pone.0141919.

104. Chu, D. J., Yao, D. E., Zhuang, Y. F., Hong, Y., Zhu, X. C., Fang, Z. R., ... \& Yu, Z. Y. (2014). Azithromycin enhances the favorable results of paclitaxel and cisplatin in patients with advanced non-small cell lung cancer. Genet Mol Res, 13(2), 2796-805.doi: $10.4238 / 2014$ 105. Mayer, M. J., Klotz, L. H., \& Venkateswaran, V. (2015). Metformin and prostate cancer stem cells: a novel therapeutic target. Prostate Cancer and Prostatic Diseases, 18(4), 303.doi: 10.1038/pcan.2015.35.

106. Jung, J. W., Park, S. B., Lee, S. J., Seo, M. S., Trosko, J. E., \& Kang, K. S. (2011). Metformin represses self-renewal of the human breast carcinoma stem cells via inhibition of estrogen receptor-mediated OCT4 expression. PLoS One, 6(11), e28068.doi: 10.1371/journal.pone.0028068.

107. Vazquez-Martin, A., Oliveras-Ferraros, C., Cufí, S., Del Barco, S., Martin-Castillo, B., \& Menendez, J. A. (2010). Metformin regulates breast cancer stem cello ntogeny by transcriptional regulation of the epithelial-mesenchymal transition (EMT) status. Cell cycle, $9(18), 3831-3838$.

108. Semenza, G. L. (2012). Hypoxia-inducible factors: mediators of cancer progression and targets for cancer therapy. Trends in pharmacological sciences, 33(4), 207-214.doi: 10.1016/j.tips.2012.01.005. 
109. Ma, W. W., \& Adjei, A. A. (2009). Novel agents on the horizon for cancer therapy. $C A$ : a cancer journal for clinicians, 59(2), 111-137. doi: 10.3322/caac.20003.

110. Kim, J. W., Tchernyshyov, I., Semenza, G. L., \& Dang, C. V. (2006). HIF-1-mediated expression of pyruvate dehydrogenase kinase: a metabolic switch required for cellular adaptation to hypoxia. Cell metabolism, 3(3), 177-185.

111. Lee, E. J., Chung, T. W., Lee, J. H., Kim, B. S., Kim, E. Y., Lee, S. O., \& Ha, K. T. (2018). Water-extracted branch of Cinnamomum cassia promotes lung cancer cell apoptosis by inhibiting pyruvate dehydrogenase kinase activity. Journal of pharmacological sciences, 138(2), 146-154.doi: 10.1016/j.jphs.2018.10.005.

112. Liu, H., Lv, L., Yang, K. Chemotherapy targeting cancer stem cells. (2015). American journal of cancer research, 5(3), 880-93.

113. Biddle, A., Gammon, L., Liang, X., Costea, D. E., \& Mackenzie, I. C. (2016). Phenotypic plasticity determines cancer stem cell therapeutic resistance in oral squamous cell carcinoma. EBioMedicine, 4, 138-145. doi: 10.1016/j.ebiom.2016.01.007.

114. Pinski, J., Parikh, A., Bova, G. S., \& Isaacs, J. T. (2001). Therapeutic implications of enhanced G0/G1 checkpoint control induced by coculture of prostate cancer cells with osteoblasts. Cancer research, 61(17), 6372-6376.

115. Mahalingam, D., Wilding, G., Denmeade, S., Sarantopoulas, J., Cosgrove, D., Cetnar, J., ...\& Carducci, M. (2016). Mipsagargin, a novel thapsigargin-based PSMA-activated prodrug: results of a first-in-man phase I clinical trial in patients with refractory, advanced or metastatic solid tumours. British journal of cancer, 114(9), 986.

116. Munster, P. N., Troso-Sandoval, T., Rosen, N., Rifkind, R., Marks, P. A., \& Richon, V. M. (2001). The histone deacetylase inhibitor suberoylanilide hydroxamic acid induces differentiation of human breast cancer cells. Cancer research, 61(23), 8492-8497. 
117. Salvador, M. A., Wicinski, J., Cabaud, O., Toiron, Y., Finetti, P., Josselin, E., ...\& Collette, Y. (2013). The histone deacetylase inhibitor abexinostat induces cancer stem cells differentiation in breast cancer with low Xist expression. Clinical cancer research, 19(23), 6520-6531. doi: 10.1158/1078-0432.CCR-13-0877.

118. Olmeda, D., Moreno-Bueno, G., Flores, J. M., Fabra, A., Portillo, F., \& Cano, A. (2007). SNAI1 is required for tumor growth and lymph node metastasis of human breast carcinoma MDA-MB-231 cells. Cancer research, 67(24), 11721-11731.119. Bedogni, B. (2014). Notch signaling in melanoma: interacting pathways and stromal influences that enhance Notch targeting. Pigment cell \& melanoma research, 27(2), 162-168.doi: 10.1111/pcmr.12194. 120. Feng, Y. X., Sokol, E. S., Del Vecchio, C. A., Sanduja, S., Claessen, J. H., Proia, T. A., ... \& Gupta, P. B. (2014). Epithelial-to-mesenchymal transition activates PERK-eIF2 $\alpha$ and sensitizes cells to endoplasmic reticulum stress. Cancer discovery, 4(6), 702-715.doi: 10.1158/2159-8290.CD-13-0945.

121. Shen, Y. A., Wang, C. Y., Hsieh, Y. T., Chen, Y. J., \& Wei, Y. H. (2015). Metabolic reprogramming orchestrates cancer stem cell properties in nasopharyngeal carcinoma. Cell cycle, 14(1), 86-98. doi: 10.4161/15384101.2014.974419.

122. Chae, Y. C., \& Kim, J. H. (2018). Cancer stem cell metabolism: target for cancer therapy. BMB reports, 51(7), 319.

123. Junk, D. J., Bryson, B. L., Smigiel, J. M., Parameswaran, N., Bartel, C. A., \& Jackson, M. W. (2017). Oncostatin M promotes cancer cell plasticity through cooperative STAT3SMAD3 signaling. Oncogene, 36(28), 4001. doi: 10.1038/onc.2017.33.

124. Chen, X., Hu, L., Yang, H., Ma, H., Ye, K., Zhao, C., ...\& Fang, Z. (2019). DHHC protein family targets different subsets of glioma stem cells in specific niches. Journal of Experimental \& Clinical Cancer Research, 38(1), 25.doi: 10.1186/s13046-019-1033-2. 
125. Joseph, D., Gonsky, J. P., \& Blain, S. W. (2018). Macrophage Inhibitory Factor-1 (MIF1) controls the plasticity of multiple myeloma tumor cells. PloS one, 13(11), e0206368. doi: 10.1371/journal.pone.0206368.

126. Bordji, K., Grandval, A., Cuhna-Alves, L., Lechapt-Zalcman, E., \& Bernaudin, M. (2014). Hypoxia-inducible factor-2 $\alpha$ (HIF-2 $\alpha$ ), but not HIF-1 $\alpha$, is essential for hypoxic induction of class III $\beta$-tubulin expression in human glioblastoma cells. The FEBS journal, 281(23), 5220-5236.

127. Nishino, H., Takano, S., Yoshitomi, H., Suzuki, K., Kagawa, S., Shimazaki, R., ...\& Ohtsuka, M. (2017). Grainyhead-like 2 (GRHL 2) regulates epithelial plasticity in pancreatic cancer progression. Cancer medicine, 6(11), 2686-2696. doi: 10.1002/cam4.1212. 128.Murgai, M., Ju, W., Eason, M., Kline, J., Beury, D. W., Kaczanowska, S., ...\& Cherepanova, O. A. (2017). KLF4-dependent perivascular cell plasticity mediates premetastatic niche formation and metastasis. Nature medicine, 23(10), 1176.doi: 10.1038/nm.4400.

129. Kosty, J., Lu, F., Kupp, R., Mehta, S., \& Lu, Q. R. (2017). Harnessing OLIG2 function in tumorigenicity and plasticity to target malignant gliomas. Cell Cycle, 16(18), 1654-1660. doi: $10.1080 / 15384101.2017 .1361062$.

130. O’Brien-Ball, C., \& Biddle, A. (2017). Reprogramming to developmental plasticity in cancer stem cells. Developmental biology, 430(2), 266-274. doi:10.1016/j.ydbio.2017.07.025. 131. Soundararajan, R., Paranjape, A. N., Maity, S., Aparicio, A., \& Mani, S. A. (2018). EMT, stemness and tumor plasticity in aggressive variant neuroendocrine prostate cancers. Biochimica et Biophysica Acta (BBA)-Reviews on Cancer, 1870(2), 229-238.doi: 10.1016/j.bbcan.2018.06.006. 
132. Poli, V., Fagnocchi, L., \& Zippo, A. (2018). Tumorigenic cell reprogramming and cancer plasticity: interplay between signaling, microenvironment, and epigenetics. Stem cells international, 2018, 4598195. doi: 10.1155/2018/4598195.

133. Padua, M. B., Bhat-Nakshatri, P., Anjanappa, M., Prasad, M. S., Hao, Y., Rao, X., ...\& Jacobsen, M. (2018). Dependence receptor UNC5A restricts luminal to basal breast cancer plasticity and metastasis. Breast Cancer Research, 20(1), 35.doi: 10.1186/s13058-018-09635.

134. Francis, J. C., Capper, A., Ning, J., Knight, E., de Bono, J., \& Swain, A. (2018). SOX9 is a driver of aggressive prostate cancer by promoting invasion, cell fate and cytoskeleton alterations and epithelial to mesenchymal transition. Oncotarget, 9(7), 7604. doi: 10.18632/oncotarget.24123.

135. Caragher, S. P., Shireman, J. M., Huang, M., Miska, J., Atashi, F., Baisiwala, S., ...\& Lesniak, M. S. (2019). Activation of Dopamine Receptor 2 Prompts Transcriptomic and Metabolic Plasticity in Glioblastoma. Journal of Neuroscience, 39(11), 1982-1993. doi: 10.1523/JNEUROSCI.1589-18.2018.

136. Molyneux, G., Geyer, F. C., Magnay, F. A., McCarthy, A., Kendrick, H., Natrajan, R., ...\& Reis-Filho, J. S. (2010). BRCA1 basal-like breast cancers originate from luminal epithelial progenitors and not from basal stem cells. Cell stem cell, 7(3), 403-417. doi: 10.1016/j.stem.2010.07.010.

137. Van Keymeulen, A., Rocha, A. S., Ousset, M., Beck, B., Bouvencourt, G., Rock, J., ...\& Blanpain, C. (2011). Distinct stem cells contribute to mammary gland development and maintenance. Nature, 479(7372), 189.doi: 10.1038/nature10573.

138. Bedogni, B., Warneke, J. A., Nickoloff, B. J., Giaccia, A. J., \& Powell, M. B. (2008). Notch1 is an effector of Akt and hypoxia in melanoma development. The Journal of clinical investigation, 118(11), 3660-3670. doi: 10.1172/JCI36157. 
139. Wellner, U., Schubert, J., Burk, U. C., Schmalhofer, O., Zhu, F., Sonntag, A., ...\& Brunton, V. G. (2009). The EMT-activator ZEB1 promotes tumorigenicity by repressing stemness-inhibiting microRNAs. Nature cell biology, 11(12), 1487. doi: 10.1038/ncb1998. 140. Glackin, C. A. (2018). Nanoparticle Delivery of TWIST Small Interfering RNA and Anticancer Drugs: A Therapeutic Approach for Combating Cancer. The Enzymes, 44, 83-101. 141. Beck, B., Lapouge, G., Rorive, S., Drogat, B., Desaedelaere, K., Delafaille, S., ...\& Blanpain, C. (2015). Different levels of Twist1 regulate skin tumor initiation, stemness, and progression. Cell stem cell, 16(1), 67-79. doi: 10.1016/j.stem.2014.12.002.

142. Sokol, E. S., Feng, Y. X., Jin, D. X., Tizabi, M. D., Miller, D. H., Cohen, M. A., ... \& Jaenisch, R. (2017). SMARCE1 is required for the invasive progression of in situ cancers. Proceedings of the National Academy of Sciences, 114(16), 4153-4158.doi: 10.1073/pnas.1703931114.

143. Tang, B., Qi, G., Tang, F., Yuan, S., Wang, Z., Liang, X., ...\& Wei, Y. (2016). Aberrant JMJD3 Expression Upregulates Slug to Promote Migration, Invasion, and Stem Cell-Like Behaviors in Hepatocellular Carcinoma. Cancer research, 76(22), 6520-6532. doi:10.1158/0008-5472.CAN-15-3029.

144. Samanta, S., Sun, H., Goel, H. L., Pursell, B., Chang, C., Khan, A., ...\& Mercurio, A. M. (2016). IMP3 promotes stem-like properties in triple-negative breast cancer by regulating SLUG. Oncogene, 35(9), 1111. doi: 10.1038/onc.2015.164.

145. Cordenonsi, M., Zanconato, F., Azzolin, L., Forcato, M., Rosato, A., Frasson, C., ...\& Daidone, M. G. (2011). The Hippo transducer TAZ confers cancer stem cell-related traits on breast cancer cells. Cell, 147(4), 759-772. doi: 10.1016/j.cell.2011.09.048.

146. Breindel, J. L., Skibinski, A., Sedic, M., Wronski-Campos, A., Zhou, W., Keller, P. J., ...\& Kuperwasser, C. (2017). Epigenetic reprogramming of lineage-committed human 
mammary epithelial cells requires DNMT3A and loss of DOT1L. Stem cell reports, 9(3), 943-955. doi:10.1016/j.stemcr.2017.06.019.

147. Gao, J. P., Xu, W., Liu, W. T., Yan, M., \& Zhu, Z. G. (2018). Tumor heterogeneity of gastric cancer: From the perspective of tumor-initiating cell. World journal of gastroenterology, 24(24), 2567. doi: 10.3748/wjg.v24.i24.2567.

148. Wong, A. L., Hirpara, J. L., Pervaiz, S., Eu, J. Q., Sethi, G., \& Goh, B. C. (2017). Do STAT3 inhibitors have potential in the future for cancer therapy?.Expert Opinion Investigation Drugs, 26(8), 883-887. doi: 10.1080/13543784.2017.1351941. 149. Dittmer, J., Rody, A. Cancer stem cells in breast cancer. (2013). Histol Histopathol, 28(7), 827-38. doi: 10.14670/HH-28.827.

150. Tuynder, M., Susini, L., Prieur, S., Besse, S., Fiucci, G., Amson, R., \& Telerman, A. (2002). Biological models and genes of tumor reversion: cellular reprogramming through tpt1/TCTP and SIAH-1. Proceedings of the National Academy of Sciences, 99(23), 1497614981.

151. Tuynder, M., Fiucci, G., Prieur, S., Lespagnol, A., Géant, A., Beaucourt, S., ...\& Moras, D. (2004). Translationally controlled tumor protein is a target of tumor reversion. Proceedings of the National Academy of Sciences, 101(43), 15364-15369.152.

Suzuki, K., Takano, S., Yoshitomi, H., Nishino, H., Kagawa, S., Shimizu, H., ...\& Ohtsuka, M. (2017). Metadherin promotes metastasis by supporting putative cancer stem cell properties and epithelial plasticity in pancreatic cancer. Oncotarget, 8(39), 66098-66111. doi: 10.18632/oncotarget.19802.

153. Rausch, V., Liu, L., Kallifatidis, G., Baumann, B., Mattern, J., Gladkich, J., ...\& Salnikov, A. V. (2010). Synergistic activity of sorafenib and sulforaphane abolishes pancreatic cancer stem cell characteristics. Cancer research, 70(12), 5004-5013. doi: 10.1158/0008-5472.CAN-10-0066. 
154. Suzuki, S., Okada, M., Shibuya, K., Seino, M., Sato, A., Takeda, H., ...\& Kitanaka, C. (2015). JNK suppression of chemotherapeutic agents-induced ROS confers chemoresistance on pancreatic cancer stem cells. Oncotarget, 6(1), 458.

155. Bao, B., Azmi, A. S., Ali, S., Zaiem, F., \& Sarkar, F. H. (2014). Metformin may function as anti-cancer agent via targeting cancer stem cells: the potential biological significance of tumor-associated miRNAs in breast and pancreatic cancers. Annals of translational medicine, 2(6), 59. doi: 10.3978/j.issn.2305-5839.2014.06.05. 


\section{Figure legends}

Figure 1: Development of plasticity or heterogeneity of CSCs. CSCs take over normal development process of cells. In normal cells, plasticity is strictly regulated by regulated interplay between activation and inactivation of transcription factors, signalling pathways, epigenetic check. In the case of cancer, cells deregulated transcriptional activation, signalling pathways, and abnormal epigenetic alterations result in the generation of plasticity.

\section{Figure 2: Roles of tumour microenvironment in the generation of CSC plasticity.} Cancer-associated fibroblast, immune cell and inflammatory cell promote CSC plasticity by various mechanisms. Tumour microenvironmental factors like hypoxia and hydrodynamic shear stress also contribute to the generation of CSCs plasticity. Straight-line indicates activation and truncated line denotes inhibition.

Figure 3: Metabolic switch and plasticity of in CSCs. Compared to normal cancer cells, CSCs maintain various metabolic phenotypes depending on the environmental stimuli and the supply of nutrient. In normoxic condition CSCs maintain combined (glycolysis+ OXPHOS) phenotype, whereas in hypoxia CSCs shift them towards glycolysis by HIFs mediated upregulation of GLUT1 and GLUT2. In nutrient deprivation state, CSCs holds a quiescent phenotype where the energy comes from the autophagy.

Figure 4: Roles of epigenetic alterations the plasticity of CSCs. Several histone modifications like acetylation, phosphorylation and methylation result in an open or closed chromatin structure, which in turn activates or represses gene expression and subsequently causes self-renewal and CSCs plasticity. Aberrant activation of chromatin remodellers like 
SWI/SNF, ISWI also promotes the plasticity of CSCs. In addition, uncontrolled activation or inactivation of methylation of DNA cytosine can give rise the plasticity to CSCs.

Table 1: Factors associated with the plasticity of CSCs

\begin{tabular}{|c|c|c|c|}
\hline Genes/Proteins/TFs & Functions & Cancer & Reference \\
\hline PTEN & $\begin{array}{l}\text { Loss of PTEN expression } \\
\text { in prostate epithelial leads } \\
\text { to increased plasticity of } \\
\text { tumour cells }\end{array}$ & Prostate cancer & [3] \\
\hline MiTF & $\begin{array}{l}\text { Regulates whether the cell } \\
\text { will differentiate, } \\
\text { proliferate, or become } \\
\text { quiescent with increased } \\
\text { migratory behaviour. }\end{array}$ & Melanoma & [7] \\
\hline Slug/Snai2 & $\begin{array}{l}\text { By repressing PUMA it } \\
\text { inhibits cell death and upon } \\
\text { cancer therapy }\end{array}$ & $\begin{array}{l}\text { Hematopoietic } \\
\text { cancer }\end{array}$ & [34] \\
\hline Snail & $\begin{array}{l}\text { Activation of Perk kinase } \\
\text { promoting therapy } \\
\text { resistance } \\
\text { through Nrf } 2 \text { activation }\end{array}$ & Pancreatic cancer & {$[17,37]$} \\
\hline Nkx2.1 & $\begin{array}{l}\text { Loss of } N k x 2.1 \text { leads to the } \\
\text { acquisition of gut fates }\end{array}$ & $\begin{array}{l}\text { Mucinous } \\
\text { adenocarcinoma }\end{array}$ & {$[38]$} \\
\hline Мyс & $\begin{array}{l}\text { Overexpression of myc is } \\
\text { the main driver of stemness } \\
\text { and glycolytic flux }\end{array}$ & $\begin{array}{l}\text { Breast, } \\
\text { Nasopharyngeal and } \\
\text { Hepatocellular } \\
\text { carcinomas. }\end{array}$ & {$[69,80]$} \\
\hline STAT3 & $\begin{array}{l}\text { Causes metabolic switch to } \\
\text { aerobic glycolysis and } \\
\text { downregulates } \\
\text { mitochondrial activity in } \\
\text { primary fibroblasts }\end{array}$ & $\begin{array}{l}\text { Glioblastoma, Breast } \\
\text { and Intestinal } \\
\text { cancer. }\end{array}$ & [81] \\
\hline IMP2 & $\begin{array}{l}\text { Induces metabolic shift to } \\
\text { OXPHOS by directly } \\
\text { interacting with } \\
\text { mitochondrial genes and } \\
\text { also regulates the stemness } \\
\text { markers including CD133, } \\
\text { Sox2, Oct4 and Nanog. }\end{array}$ & Glioma & [89] \\
\hline MCL1 & $\begin{array}{l}\text { Along with myc promote } \\
\text { chemotherapy resistant } \\
\text { CSC via the regulation of } \\
\text { mitochondrial OXPHOS }\end{array}$ & Breast cancer & [97] \\
\hline VEGF & $\begin{array}{l}\text { Induces hypoxia related } \\
\text { invasiveness }\end{array}$ & Pancreatic cancer & {$[130]$} \\
\hline
\end{tabular}




\begin{tabular}{|c|c|c|c|}
\hline MMP3 & $\begin{array}{l}\text { Induce hypoxia related } \\
\text { invasiveness }\end{array}$ & Pancreatic cancer & {$[130]$} \\
\hline Oncostatin $\mathbf{M}$ & $\begin{array}{l}\text { Promotes epithelial- } \\
\text { mesenchymal plasticity } \\
\text { through STAT3- } \\
\text { SMAD3/TGF- } \beta \text { signaling. }\end{array}$ & $\begin{array}{l}\text { Pancreatic } \\
\text { adenocarcinoma }\end{array}$ & [173] \\
\hline $\begin{array}{l}\text { DHHC protein } \\
\text { family }\end{array}$ & $\begin{array}{l}\text { DHHC protein family } \\
\text { promote CSCs plasticity in } \\
\text { low oxygen condition and } \\
\text { under less nutrient supply } \\
\text { and expression varies in } \\
\text { different subsets of } \\
\text { glioblastoma. }\end{array}$ & Glioblastoma & [174] \\
\hline MIF-1 & $\begin{array}{l}\text { Controls cancer cell } \\
\text { plasticity by conversion of } \\
\text { CD138- to CD138+ cells. }\end{array}$ & Multiple myeloma & {$[175]$} \\
\hline \multirow[t]{2}{*}{ HIF-1 and $-2 \alpha$} & $\begin{array}{l}\text { HIF- } 1 \alpha \text { promotes the } \\
\text { expression of stem cell- } \\
\text { associated transcription }\end{array}$ & Breast cancer, & {$[63]$} \\
\hline & $\begin{array}{l}\text { factor Oct } 4 \\
\text { HIF-2 } \alpha \text { facilitates the } \\
\text { release of } \\
\text { angiogenic factors and } \\
\text { promotes acquisition of a } \\
\text { CSC-like phenotype }\end{array}$ & Glioblastoma & {$[178]$} \\
\hline GRHL2 & $\begin{array}{l}\text { Positively correlates with } \\
\text { E- cadherin and CD133 } \\
\text { expression and regulates } \\
\text { epithelial plasticity along } \\
\text { with stemness }\end{array}$ & Pancreatic cancer & [179] \\
\hline KLF4 & $\begin{array}{l}\text { promotes a less } \\
\text { differentiated state } \\
\text { characterized by enhanced } \\
\text { ECM production that } \\
\text { establishes a pro-metastatic } \\
\text { niche phenotypically- } \\
\text { switched perivascular cells }\end{array}$ & $\begin{array}{l}\text { Melanoma, } \\
\text { Rhabdomyosarcoma }\end{array}$ & [180] \\
\hline OLIG2 & $\begin{array}{l}\text { Plays critical role in the } \\
\text { maintenance of tumour } \\
\text { propagating neurospheres } \\
\text { or self-renewal } \\
\text { withTrp53/Pten deletions } \\
\text { /PDGFB overexpression. }\end{array}$ & Glioblastoma & [181] \\
\hline PIK3CA & $\begin{array}{l}\text { Mutated PIK } 3 \text { CA induces } \\
\text { reprogramming of lineage } \\
\text { restricted progenitors to a } \\
\text { multipotent stem-like state } \\
\text { in breast tumour initiation }\end{array}$ & Breast cancer & [182] \\
\hline FOXC2 & $\begin{array}{l}\text { Facilitates NE trans- } \\
\text { differentiation as well as }\end{array}$ & $\begin{array}{l}\text { Neuroendocrine } \\
\text { prostate cancer }\end{array}$ & [183] \\
\hline
\end{tabular}




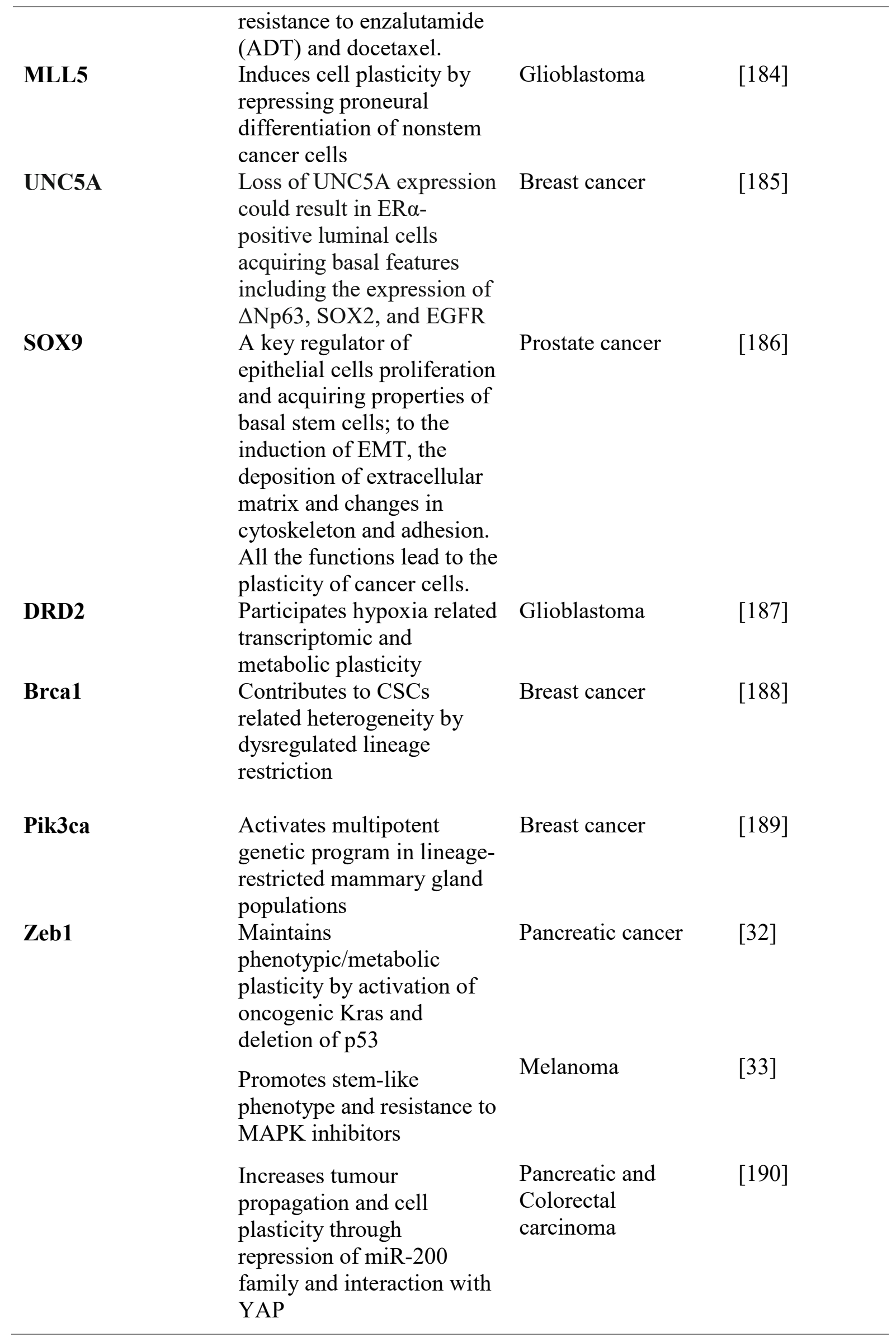




\begin{tabular}{llll}
\hline Twist1 & $\begin{array}{l}\text { Represses differentiation } \\
\text { by activation of MAPK } \\
\text { pathways }\end{array}$ & Melanoma & {$[36][191]$} \\
& $\begin{array}{l}\text { Promotes therapy } \\
\text { resistance by activating } \\
\text { therapy resistance }\end{array}$ & & \\
& $\begin{array}{l}\text { Drives invasiveness by } \\
\text { partial EMT in early stage } \\
\text { in situ tumours }\end{array}$ & Breast cancer & {$[192]$} \\
Smarce1 & $\begin{array}{l}\text { Increases tumour-initiation } \\
\text { through deposition of }\end{array}$ & Hepatocarcinoma & {$[193]$} \\
& $\begin{array}{l}\text { active histone mark on } \\
\text { Smjd3 }\end{array}$ & & \\
Snai2 promoter & & \\
Stabilizes Snai2 transcripts & Breast cancer & {$[194]$} \\
Induces plasticity and & Breast cancer & {$[195]$} \\
& $\begin{array}{l}\text { Stemness } \\
\text { in mammary epithelial cells }\end{array}$ & & \\
& $\begin{array}{l}\text { Interacts SWI/SNF } \\
\text { complex to mediate cellular } \\
\text { plasticity } \\
\text { Mutation causes the loss of } \\
\text { cell-cycle regulators and } \\
\text { lineage-specific genes }\end{array}$ & & \\
\hline
\end{tabular}

Abbreviation: Forkhead transcription factor (FOXC2); Microthalamia associated transcription factor (MATF) 
Table 2: Available therapeutic options against CSC plasticity

\begin{tabular}{|c|c|c|c|}
\hline Genes/synthetic & Functions & Cancer & Reference \\
\hline $\begin{array}{l}\text { compounds/natural } \\
\text { compounds }\end{array}$ & & & \\
\hline ATOH1 & $\begin{array}{l}\text { Overexpression of } \\
\text { ATOH1 induced } \\
\text { differentiation and } \\
\text { reduced tumourigenicity } \\
\text { both in vitro and in vivo }\end{array}$ & Gastric cancer & {$[131]$} \\
\hline $\begin{array}{l}\text { Galunisertib } \\
\text { (LY2157299) }\end{array}$ & $\begin{array}{l}\text { Inhibits TGF } \beta \text { receptor } \\
\text { kinase to prevent signal } \\
\text { transduction mediated } \\
\text { CSC growth }\end{array}$ & $\begin{array}{l}\text { PDAC (NCT01246986), } \\
\text { HCC (NCT01373164), } \\
\text { Glioma (NCT01220271), } \\
\text { Glioblastoma(NCT0217838) }\end{array}$ & {$[135]$} \\
\hline STA-21 & $\begin{array}{l}\text { Inhibits STAT3-SH2 } \\
\text { domain dimerization }\end{array}$ & Breast cancer & {$[137]$} \\
\hline LLL-3 & $\begin{array}{l}\text { Inhibits STAT3-SH2 } \\
\text { domain dimerization }\end{array}$ & Glioblastoma & {$[137]$} \\
\hline Salinomycin & $\begin{array}{l}\text { Inhibits the growth of } \\
\text { mesenchymal phenotype } \\
\text { of tumor cells }\end{array}$ & Breast cancer & {$[138]$} \\
\hline Sonidegib & $\begin{array}{l}\text { Downregulates CSCs } \\
\text { markers expression and } \\
\text { also sensitizes to } \\
\text { docetaxel }\end{array}$ & Triple negative cancer & {$[141]$} \\
\hline Menadione & $\begin{array}{l}\text { Prevents glycolytic/ } \\
\text { OXPHOS phenotype by } \\
\text { ROS }\end{array}$ & Pancreatic cancer & {$[88,152]$} \\
\hline TH-302 & $\begin{array}{l}\text { Inhibits HIF in } \\
\text { combination with } \\
\text { doxorubicin }\end{array}$ & Sarcoma & {$[154]$} \\
\hline $\begin{array}{l}\text { Cinnamomum cass } \\
\text { ia Blume }\end{array}$ & $\begin{array}{l}\text { Induces apoptosis by } \\
\text { targeting pyruvate } \\
\text { dehydrogenase kinase }\end{array}$ & Lung carcinoma & {$[156]$} \\
\hline Thapsigargin & $\begin{array}{l}\text { Selectively targets } \\
\text { quiescent CSCs }\end{array}$ & Many solid tumors & {$[160]$} \\
\hline $\begin{array}{l}\text { Suberoylanilide } \\
\text { hydroxamic acid }\end{array}$ & $\begin{array}{l}\text { Induces cancer cell } \\
\text { differentiation by } \\
\text { inhibiting histone } \\
\text { deacetylase }\end{array}$ & Breast cancer & {$[161]$} \\
\hline Abexinostat & $\begin{array}{l}\text { Induces cancer cell } \\
\text { differentiation by } \\
\text { inhibiting histone } \\
\text { deacetylase }\end{array}$ & Breast cancer & {$[162]$} \\
\hline TCTP & $\begin{array}{l}\text { Repeals the malignancy } \\
\text { through partially } \\
\text { recovering the function of } \\
\text { the P53/MDM } 2 \text { axis }\end{array}$ & Breast cancer, Lymphoma & {$[168-170]$} \\
\hline Metadherin & $\begin{array}{l}\text { Facilitates MET by } \\
\text { suppressing Twist } 1 \text { and }\end{array}$ & PDAC & {$[197]$} \\
\hline
\end{tabular}




\begin{tabular}{|c|c|c|c|}
\hline & $\begin{array}{l}\text { contributes to anoikis } \\
\text { resistance. }\end{array}$ & & \\
\hline Sorafenib & $\begin{array}{l}\text { Decreases colony } \\
\text { outgrowth, tumoursphere } \\
\text { formation, ALDH1 } \\
\text { activity, and tumour- } \\
\text { initiating capacity by } \\
\text { inhibiting downstream } \\
\text { multikinase }\end{array}$ & Pancreatic cancer & {$[198]$} \\
\hline 5-Flurouracil & $\begin{array}{l}\text { Targeting JNK signaling } \\
\text { to increase chemotherapy } \\
\text { sensitivity of CSC }\end{array}$ & Pancreatic cancer & [199] \\
\hline Gemcitabine & $\begin{array}{l}\text { Targeting JNK signaling } \\
\text { to increase chemotherapy } \\
\text { sensitivity of CSC }\end{array}$ & Pancreatic cancer & [199] \\
\hline \multirow[t]{2}{*}{ Metformin } & $\begin{array}{l}\text { Diminishes cell growth } \\
\text { and proliferation by pro- } \\
\text { oncogenic pathway } \\
(\mathrm{NF}-\mathrm{kB} \text { and HIF-1 } \alpha) \\
\text { mediated inhibition of } \\
\text { pro-inflammatory } \\
\text { cytokines like TNF- } \alpha \text { and } \\
\text { IL-6, as well as } \\
\text { angiogenic cytokine } \\
\text { VEGF }\end{array}$ & Pancreatic cancer & {$[200]$} \\
\hline & $\begin{array}{l}\text { Inhibits the CSC } \\
\text { metabolic switch from } \\
\text { OXPHOS to glycolysis }\end{array}$ & Pancreatic cancer & {$[88]$} \\
\hline
\end{tabular}

PDAC: Pancreatic ductal adenocarcinoma 